\title{
30.2. OXYGEN, CARBON, SULFUR, AND HYDROGEN STABLE ISOTOPES IN CARBONATE AND SULFATE MINERAL PHASES OF NEOGENE EVAPORITES, SEDIMENTS, AND IN INTERSTITIAL WATERS
}

\author{
J-Ch. Fontes, R. Letolle, W. D. Nesteroff, Laboratoire de Géologie Dynamique, University of Paris, Ve \\ and \\ William B. F. Ryan, Lamont-Doherty Geological Observatory of Columbia University, Palisades, New York
}

\section{INTRODUCTION}

The relative abundance of certain elements and their stable isotopes sometimes indicates the environmental conditions under which discrete mineral phases originate. In the case of the sediments and sedimentary rocks recovered during Leg 13 , we were particularly anxious to examine the environment of formation of the late Miocene (Messinian) evaporites.

The evaporite minerals calcite, dolomite, anhydrite, and gypsum were available from Sites 122, 124, and 134 in the western Mediterranean; Site 132 in the central Tyrrhenian Basin; and Sites 125 and 129 in the eastern Mediterranean (see Figure 1). The materials consist of unaltered authigenic components (fine-grained anhedral dolomite in the gray marls of Cores $6,7,10,11$, and 13 of Hole 124) and minerals formed through secondary replacement and hydration (crystals of selenite in the Core Bit sample of Holes 122 and $125 \mathrm{~A}$ ). The scope of this preliminary research included determination of the source of water which supplied the brine basin during precipitation of at least part of the evaporite series, and elucidation of the conditions leading to replacement of anhydrite by gypsum or to the recrystallization of gypsum.

A second objective was an evaluation of the isotopic composition of carbon and oxygen in the bulk carbonate of the Serravallian open-marine sediments below the evaporites, and the Pliocene and Pleistocene pelagic oozes above. The purpose of this effort was to determine the environmental setting of the Mediterranean Basin before and after the late Miocene "crisis of salinity" (Ruggieri, 1967).

\section{Sample Coverage}

In the time allowed for this study we were able to make $\delta \mathrm{O}^{18}$ and $\delta \mathrm{C}^{13}$ analyses on 7 samples of Serravallian sediments from Holes 126 and 129,12 samples of the Pliocene and Pleistocene pelagic oozes from Holes 125A, 132 and 134, and 32 samples of Messinian calcites and dolomites. The results of these analyses, grouped by drillhole, are listed in Table 1. Also included is the mineralogy of these samples and an approximation as to the amount of calcite and dolomite present in each sample.

Two complete $\delta \mathrm{O}^{18}$ and $\delta \mathrm{S}^{34}$ analyses of sulfate ions in gypsum from drill bit samples of Holes 122 and $125 \mathrm{~A}$ were made, as well as $\delta \mathrm{O}^{18}$ and $\delta \mathrm{D}$ analyses of water of hydration (Table 2). $\delta \mathrm{O}^{18}$ and $\delta \mathrm{D}$ analyses of interstitial waters from dolomitic marls of the evaporite sequence in Hole 132 were also made (Table 3 ).

\section{ISOTOPIC COMPOSITION OF THE EVAPORITES}

The evaporites illustrated in Figure 1 include layers of carbonate marls, anhydrite, gypsum, and halite. The most complete sections are from Site 124, on the Balearic Rise, and Site 132, in the Tyrrhenian Basin. With the exception of some minor amounts of gypsum in Core 7, the calcium sulfate phase at Site 124 , is almost entirely anhydrite (see chapters 6, 21 and 22.1). At Site 132, however, similar anhydrite has been completely replaced by gypsum (see Chapter 22.1). Present at both of these sites, and also at Sites $125 \mathrm{~A}, 129$, and 134 , are interbeds of steel blue to gray marls, which are occasionally finely laminated, and possess a variable amount of fine-grained anhedral dolomite. Similar dolomitic and calcitic marls were recovered from Holes 125A, 129A, 134 and 134D.

\section{Oxygen and Carbon Isotopes in the Carbonates}

At times calcite and dolomite occur together $\mathrm{m}$ the evaporite marls. When fossil tests are present they are always calcitic. Siderite was identified in Sample $132-26-1-20 \mathrm{~cm}$. The total carbonate content is usually less than 30 per cent; the other components consist of terrigenous clastic minerals (fine-grained quartz, clay minerals), pyrite, and disseminated organic matter. Smectites are the most important clay minerals. The relative proportions of other minerals do not seem to change significantly with changes in the abundance of gypsum and anhydrite, as if they represent some kind of background sedimentation.

The isotopic compositions of the carbonates are dispersed between two extremes: pure calcite and pure dolomite.

Calcites: The pure calcites, depicted by the solid dots in Figure 2, exhibit: (1) low values of $\delta \mathrm{O}^{18}$ and $\delta \mathrm{C}^{13}$ in comparison to normal marine pelagic oozes (open circles), (2) distinctly lower $\delta \mathrm{O}^{18}$ than the Messinian dolomites, and (3) a large scatter of $\delta \mathrm{O}^{18}$ and $\delta \mathrm{C}^{13}$ values, with all the values grouped in the quadrant of negative oxygen and negative carbon ranges.

Because the Pliocene and Quaternary pelagic oozes all cluster in the quadrant of positive oxygen and carbon ranges, it is isotopically easy to delineate the Miocene/Pliocene boundary (see also Figure 2 of Chapter 30.3). In Hole 132 where the Messinian marls in Core 21-2 are calcitic, the evaporite marl/pelagic ooze contact is accompanied by a pronounced decrease in both $\delta \mathrm{O}^{18}$ and $\delta \mathrm{C}^{13}$. In Hole 134 there is a similar change. However, in Hole 125A, from the Mediterranean Ridge in the Ionian Basin, the underlying marls are dolomitic, with no calcite, and thus we observe a decrease only in $\delta C^{13}$ (i.e. a trend toward more negative values). 


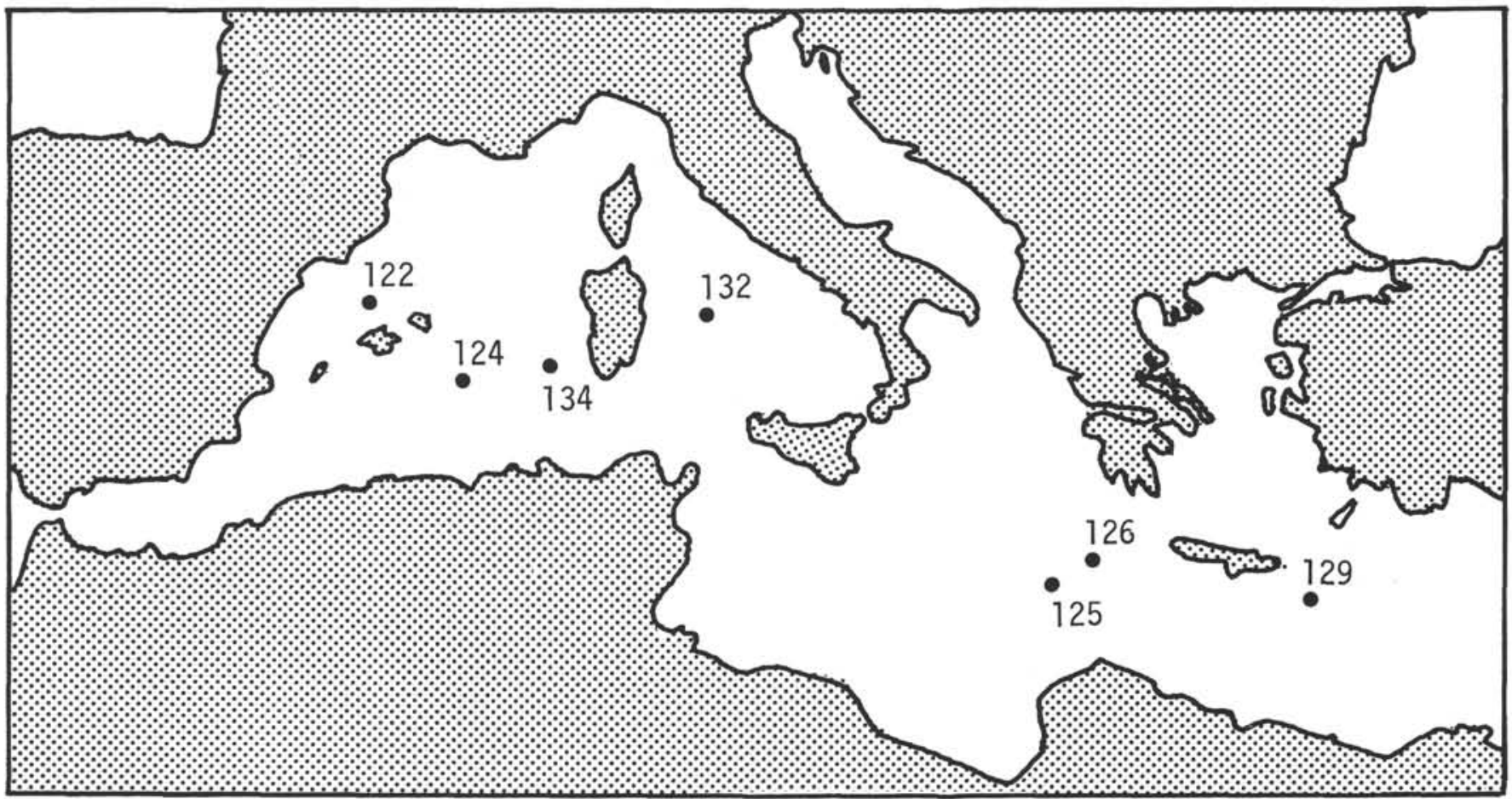

Figure 1. Location of the drill sites from which samples have been taken for the measurements of stable isotopes.

In the apparently continuous section at Site 132 in the Tyrrhenian Basin, the isotopic shift at the Miocene/Pliocene boundary, in Core 21-2, from negative to positive values is obviously related to the abrupt termination of evaporite conditions and the filling of the basin with normal marine water. The shift can be explained as being the result of an influx of cold North Atlantic deep water, replacing a warm water body of meteoric origin, already greatly depleted in the heavy isotope of oxygen. The concept that the terminal phase of the evaporite epoch was accompanied by the widespread occurrence of alkaline lakes is collaborated by the finding of the "Melanopsis-Cyprideis" fauna in the upper Messinian "lago mare" facies of northern Sicily (Ruggieri and Greco, 1965). We doubt that the isotopic shift can be entirely due to temperature because there is also a marked change in the carbon isotope ratio from negative to positive values. Yet the $\mathrm{C}^{13}$ fractionation with temperature is known to be much lower than $\mathrm{O}^{18}$ fractionation (Mook, 1971).

Dolomites: The marls characterized by the presences of dolomite without calcite (solid triangles in Figure 2) are, in the vast majority of cases, isotopically distinct from the calcites. Except for three samples from Core 25 of Hole 132 , all of the dolomite samples have quite highly positive $\delta \mathrm{O}^{18}$ values, with a mean of about $+4 \%$ PDB. With one exception, the Site 124 (Balearic Rise) dolomites all group rather tightly (i.e. $3.34>\delta \mathrm{O}^{18}>2.14$ and $2.16>\delta \mathrm{C}^{13}>$ 0.27 ) in the positive quadrant of Figure 2 within the range of dolomites related to evaporite environments (Clayton et al., 1968).

The one negative measurement is from Core 7 of this drill hole; the sample has a $\delta 018$ of $-4.73 \%$ and is associated with secondary gypsum replacement in the form of selenite (see Figure 18A of Chapter 22.1). In this case the carbonate is a mixture of calcite and dolomite and the low $\mathrm{O}^{18}$ content can be explained by the predominance of an isotopically light calcite (calcisparite). In each of these samples the $\delta \mathrm{C}^{13}$ is also negative, reaching $-6.34 \%$ in Sample $132-25-2-70 \mathrm{~cm}$. This suggests that meteoritic water has probably played an important role in the formation of the dolomite-perhaps as secondary dolosparite.

Some very low $\delta \mathrm{C}^{13}$ values have been obtained in samples from the eastern Mediterranean Basin. Both samples, 129-2-1 (Strabo Trench) and 125A-DB (Mediterranean Ridge - Ionian Basin), contain faunas indicative of a brackish water environment (see documentation in Chapters 7 and 10). Thus it is easy to accept that these ratios reflect the input of fresh water into the eastern basins and the development there of Alkaline lakes in late Messinian time (see Chapter 36.2).

However, the low $\delta \mathrm{C} 13$ values may also be attributed to the contribution of carbon dioxide of biogenic origin in the bicarbonate ion system. In fact, sample 134-10-1 $(\delta \mathrm{C} 13=$ $-9.57 \%$ ) is from an interval rich in gasoline range hydrocarbons (see Chapter 32). The suggestion of biological influence has been presented by Dessau et al. (1960) and Cheney and Jensen (1965) for carbonates connected with the Sicilian evaporite beds and by others (Russell et al., 1967; Hathaway and Degens, 1970; Deuser, 1970) for various sedimentological systems at other locations.

Whereas the primary isotopic composition of calcites may change during diagenesis, dolomites generally do not undergo very much exchange (Fritz, 1971). The negative $\delta \mathrm{C} 13$ values for the dolomitic marls of Sites $125 \mathrm{~A}$ and 129 are lower than those given by Fritz (1970) for secondary dolomite and suggest that some of the very fine anhedral 
TABLE 1

Oxygen and Carbon Isotopic Composition of Selected Samples of the Evaporitic Marls and Pelagic Sediments

\section{WESTERN MEDITERRANEAN DRILLSITES}

\begin{tabular}{|c|c|c|c|c|c|c|}
\hline \multicolumn{5}{|c|}{ Site 122 - Valencia Trough } & \multicolumn{2}{|c|}{ Balearic Basin } \\
\hline \multirow[b]{2}{*}{ Age } & \multirow[b]{2}{*}{ Sample } & \multicolumn{2}{|c|}{ Per Cent } & \multirow{2}{*}{$\begin{array}{l}\text { Mineralogical Content and } \\
\text { Other Components }\end{array}$} & \multirow{2}{*}{\multicolumn{2}{|c|}{$\delta \mathrm{O}^{18}$ vs PDB }} \\
\hline & & Calcite & Dolomite & & & \\
\hline $\begin{array}{c}-162 \mathrm{my} \\
\stackrel{b}{\mathrm{\Sigma}} \stackrel{0}{8}\end{array}$ & Core Bit & H & $\mathrm{T}$ & n.d. & -3.24 & +0.02 \\
\hline
\end{tabular}

Site 124 - Balearic Rise

Balearic Basin

\begin{tabular}{|c|c|c|c|c|c|c|}
\hline 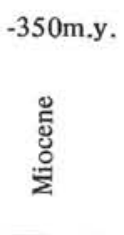 & $\begin{array}{l}6 \\
7 \\
10-1 \quad(113) \\
10 \mathrm{CC} \\
10 \mathrm{CC} \\
11-1 \quad(124) \\
13-2 \quad(35)\end{array}$ & $\begin{array}{l}0 \\
+ \\
0 \\
0 \\
0 \\
0 \\
0\end{array}$ & $\begin{array}{r}60 \\
+ \\
+ \\
+ \\
+ \\
85 \\
++\end{array}$ & $\begin{array}{l}\text { I, Ch, Q, M, G } \\
\text { G, Q+ n.d. } \\
\text { n.d. } \\
\text { n.d. } \\
\text { n.d. } \\
\text { Q, I, M, K } \\
\text { n.d. }\end{array}$ & $\begin{array}{l}+2,14^{\mathrm{x}} \\
-4,73 \\
+3,34^{\mathrm{x}} \\
+2,42^{\mathrm{x}} \\
+2,56^{\mathrm{x}} \\
+3,08^{\mathrm{x}} \\
+3,29^{\mathrm{x}}\end{array}$ & $\begin{array}{l}+1,27 \\
-2,43 \\
-2,16 \\
+2,15 \\
+2,22 \\
+1,74 \\
+0,27\end{array}$ \\
\hline
\end{tabular}

Site 132 - Tyrrhenian Rise

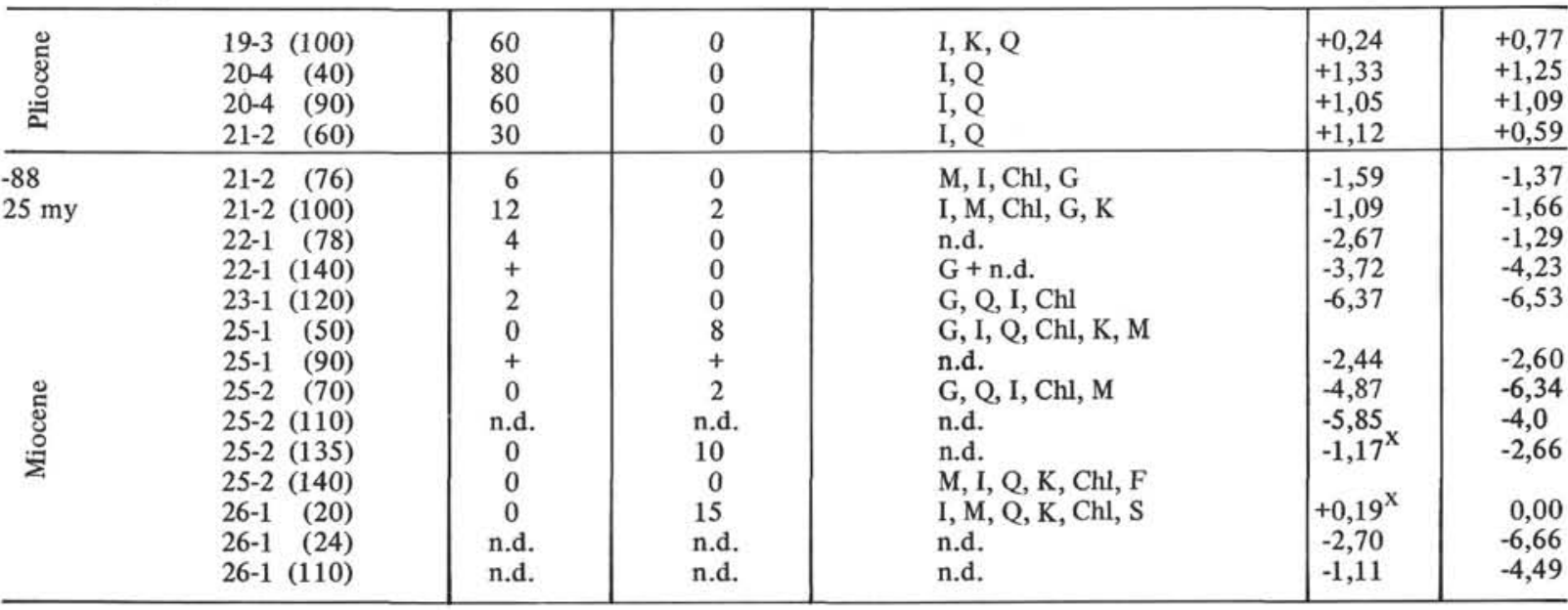

\begin{tabular}{|c|c|c|c|c|c|c|}
\hline \multicolumn{5}{|c|}{ Site 134 - Balearic Abyssal Plain } & \multicolumn{2}{|c|}{ Balearic Basin } \\
\hline $\begin{array}{l}\text { ్ㅐㅇ } \\
\text { : }\end{array}$ & $\begin{array}{l}3-1 \quad(126) \\
3-2 \quad(130) \\
3 \mathrm{CC} \\
5 \mathrm{CC} \\
\end{array}$ & $\begin{array}{l}+ \\
+ \\
+ \\
+\end{array}$ & $\begin{array}{l}0 \\
0 \\
0 \\
0 \\
\end{array}$ & $\begin{array}{l}\text { n.d. } \\
\text { n.d. } \\
\text { n.d. } \\
\text { n.d. }\end{array}$ & $\begin{array}{l}+0,68 \\
+0,91 \\
+0,99 \\
\end{array}$ & $\begin{array}{l}+0,25 \\
+0,55 \\
+0,82 \\
\end{array}$ \\
\hline $\begin{array}{c}-326 \mathrm{~m} . \mathrm{y} . \\
\text { 월 }\end{array}$ & $\begin{array}{l}7-5 \quad(140) \\
7 \text { CC (24) } \\
10-1(115)\end{array}$ & $\begin{array}{r}+ \\
15 \\
0\end{array}$ & $\begin{array}{r}+ \\
15 \\
+\end{array}$ & $\begin{array}{l}\text { n.d. } \\
\text { Q, I, M, Chl. } \\
\text { A, H, Q }\end{array}$ & $\begin{array}{l}+0,10 \\
-1,76 \\
+4.60^{x}\end{array}$ & $\begin{array}{l}+0,08 \\
-1,32 \\
-9.57\end{array}$ \\
\hline \multicolumn{5}{|c|}{ Site 134 - Western Sardinia Slope } & \multicolumn{2}{|c|}{ Balearic Basin } \\
\hline $\begin{array}{c}-183 \mathrm{my} \\
\text { 일 }\end{array}$ & $\begin{array}{rr}1-1 & (90) \\
1-1 & (144)\end{array}$ & $\begin{array}{r}14 \\
T\end{array}$ & $\begin{array}{l}2 \\
\mathrm{~T}\end{array}$ & $\begin{array}{l}\text { G, M, I, Ch, Q } \\
\text { G, Q, I, Chl, M }\end{array}$ & $\begin{array}{l}+2.41 \\
+2.96\end{array}$ & $\begin{array}{l}+1.93 \\
+1.92\end{array}$ \\
\hline
\end{tabular}

dolomite in the evaporite marls might indeed be an early diagenetic product.

A more detailed petrographic analysis is needed to fully evaluate the problems of diagenesis. However, if, as we believe, some of the dolomites and calcites have preserved their original primary isotopic composition it must be accepted that the Mediterranean Sea at certain times was fed predominantly from rivers and rainfall and that the evaporite basins were isolated from the open sea. The great variations in the isotopic composition of the calcite indicate that the influence of fresh water was intermittent. In the case of the dolomites of Site 124, the mineral phase was 
TABLE 1-Continued

\section{EASTERN MEDITERRANEAN DRILLSITES}

Site 125A - Mediterranean Ridge

Ionian Basin

\begin{tabular}{|c|c|c|c|c|c|c|}
\hline \multirow[b]{2}{*}{ Age } & \multirow[b]{2}{*}{ Sample } & \multicolumn{2}{|c|}{ Per Cent } & \multirow{2}{*}{$\begin{array}{l}\text { Mineralogical Content and } \\
\text { Other Components }\end{array}$} & \multirow{2}{*}{\multicolumn{2}{|c|}{$\delta \mathrm{O}^{18}$ vs PDB }} \\
\hline & & Calcite & Dolomite & & & \\
\hline 힐 & $\begin{array}{ll}2-2 & (66) \\
5-3 & (48) \\
6-1 & (25) \\
\end{array}$ & $\begin{array}{l}60 \\
64 \\
65 \\
\end{array}$ & $\begin{array}{r}0 \\
4 \\
10\end{array}$ & $\begin{array}{l}\mathrm{G}, \mathrm{Q}, \mathrm{I} \\
\mathrm{I}, \mathrm{Q}, \mathrm{K} \\
\mathrm{I}, \mathrm{Q}, \mathrm{K}\end{array}$ & $\begin{array}{r}+0,37 \\
+1,10 \\
+1,48 \\
\end{array}$ & $\begin{array}{r}-0,04 \\
+0,91 \\
+1,23 \\
\end{array}$ \\
\hline 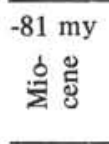 & $\begin{array}{l}6-1 \quad(150) \\
7 \mathrm{CC}(140) \\
9-1 \quad(113) \\
\text { Drillbit }\end{array}$ & $\begin{array}{l}0 \\
0 \\
0 \\
0\end{array}$ & $\begin{array}{l}++ \\
25 \\
++ \\
++\end{array}$ & $\begin{array}{l}\text { n.d. } \\
\text { I, Q, K, F } \\
\text { n.d. } \\
\text { A + n.d. }\end{array}$ & $\begin{array}{l}+5,20^{\mathrm{x}} \\
+4,38^{\mathrm{x}} \\
+5,23^{\mathrm{x}} \\
+5,09^{\mathrm{x}}\end{array}$ & $\begin{array}{r}-1,08 \\
-0,92 \\
-3,28 \\
-11,66\end{array}$ \\
\hline
\end{tabular}

Site 126 - Cleft in Mediterranean Ridge

\begin{tabular}{|c|c|c|c|c|c|c|}
\hline 岕 & $1-4 \quad(90)$ & 60 & 4 & I, Q, K, Chl & $+1,35$ & $+0,49$ \\
\hline 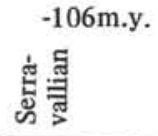 & $\begin{array}{l}5-1 \quad(130) \\
5 \mathrm{CC} \\
6-1 \quad(130) \\
6 \mathrm{CC}\end{array}$ & $\begin{array}{r}12 \\
6 \\
3 \\
4\end{array}$ & $\begin{array}{l}0 \\
0 \\
0 \\
0\end{array}$ & $\begin{array}{l}\text { M, K, Q, I } \\
\text { M, K, Q } \\
\text { M, K. I, Q } \\
\text { Q, + n.d. }\end{array}$ & $\begin{array}{l}+0,48 \\
+0,72 \\
+2,71 \\
+0,19\end{array}$ & $\begin{array}{l}+0,27 \\
+0,33 \\
+0,65 \\
-2,83\end{array}$ \\
\hline
\end{tabular}

Site 129 - Strabo Trench

Levantine Basin

\begin{tabular}{|c|c|c|c|c|c|c|}
\hline 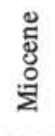 & $\begin{array}{lr}2-C e n t e r b i t \\
2-1 \quad(136) \\
3-1 \quad(49) \\
3 \mathrm{CC}\end{array}$ & $\begin{array}{c}++ \\
0 \\
\text { n.d. } \\
15\end{array}$ & $\begin{array}{c}0 \\
25 \\
\text { n.d. } \\
13\end{array}$ & $\begin{array}{l}\text { n.d. } \\
\text { Q, M, Chl, I, G } \\
\text { n.d. } \\
\text { M, Q, I, Chl, K }\end{array}$ & $\begin{array}{r}-6,81 \\
+1,60 x \\
-0,83 \\
+0,17\end{array}$ & $\begin{array}{r}-1,92 \\
-26,90 \\
-8,22 \\
-7,51\end{array}$ \\
\hline
\end{tabular}

Site 129A - Strabo Mountains

Levantine Basin

\begin{tabular}{ll|l|l|l|l|l|l|}
\multicolumn{4}{c|}{ Levantine Basin } \\
\hline \multirow{2}{*}{$2 \mathrm{CC}$} & 15 & 10 & M, Q, I, Chl & -2.21 & -1.97 \\
\hline
\end{tabular}

LEGEND: $\mathrm{T}=$ trace, $\mathrm{n}$.d. not measured. $\mathrm{G}=$ gypsum, $\mathrm{I}=$ illite, $\mathrm{M}=$ montmorillonite, $\mathrm{Q}=\mathrm{quartz}, \mathrm{K}=\mathrm{kaolinite}, \mathrm{F}=$ feldspars $\mathrm{Chl}=$ chlorite, $\mathrm{A}=$ clays, $\mathrm{H}=$ halite, $\mathrm{S}=$ siderite.

The mineralogical components are given in the order of their relative importance. The isotopic values for pure dolomites ( $\mathrm{x}$ ) have been corrected for isotopic fractionation effect as given by Sharma and Clayton (1965).

TABLE 2

Isotope Composition of Gypsum

\begin{tabular}{|c|c|c|c|c|c|c|c|}
\hline \multirow[b]{2}{*}{ Site } & \multirow[b]{2}{*}{ Location } & \multirow[b]{2}{*}{ Sample } & \multirow[b]{2}{*}{ Facies } & \multicolumn{2}{|c|}{ Crystallization Water } & \multicolumn{2}{|c|}{ Sulfate Ion } \\
\hline & & & & $\delta 0^{18^{a}}$ & $\delta \mathrm{D}^{\mathrm{a}}$ & $\delta S^{34 b}$ & $\delta \mathrm{O}^{18^{\mathrm{a}}}$ \\
\hline $\begin{array}{l}122 \\
125 \mathrm{~A}\end{array}$ & $\begin{array}{l}\text { Valencia trough } \\
\text { Ionian Basin }\end{array}$ & $\begin{array}{l}\text { Core Bit } \\
\text { Core Bit }\end{array}$ & $\begin{array}{l}\text { Selenite gravel } \\
\text { Selenite chips }+++ \\
\text { traces Fe }\end{array}$ & $\begin{array}{l}+4.07 \\
+3.89 \\
\end{array}$ & $\begin{array}{r}-16.0 \\
-8.5 \\
\end{array}$ & $\begin{array}{l}+22.0 \\
+22.6 \\
\end{array}$ & +14.3 \\
\hline
\end{tabular}

a vs SMOW

TABLE 3

Isotope Composition of Interstitial Waters

\begin{tabular}{|c|c|c|c|c|c|}
\hline \multirow[b]{2}{*}{ Site } & \multirow[b]{2}{*}{ Location } & \multirow[b]{2}{*}{ Sample } & \multirow[b]{2}{*}{ Dry Residue } & \multicolumn{2}{|c|}{ Pore Water } \\
\hline & & & & $\delta \mathrm{O}^{18^{\mathrm{a}}}$ & $\delta \mathrm{D}^{\mathrm{a}}$ \\
\hline 132 & Tyrrhenian Basin & $25-2125 \mathrm{~cm}$ & $53.80 / 00$ & -0.78 & +6.4 \\
\hline 132 & Tyrrhenian Basin & $25-1,15 \mathrm{~cm}$ & $55.00 / 00$ & -0.88 & +4.3 \\
\hline
\end{tabular}

a vs SMOW

vs C.D 


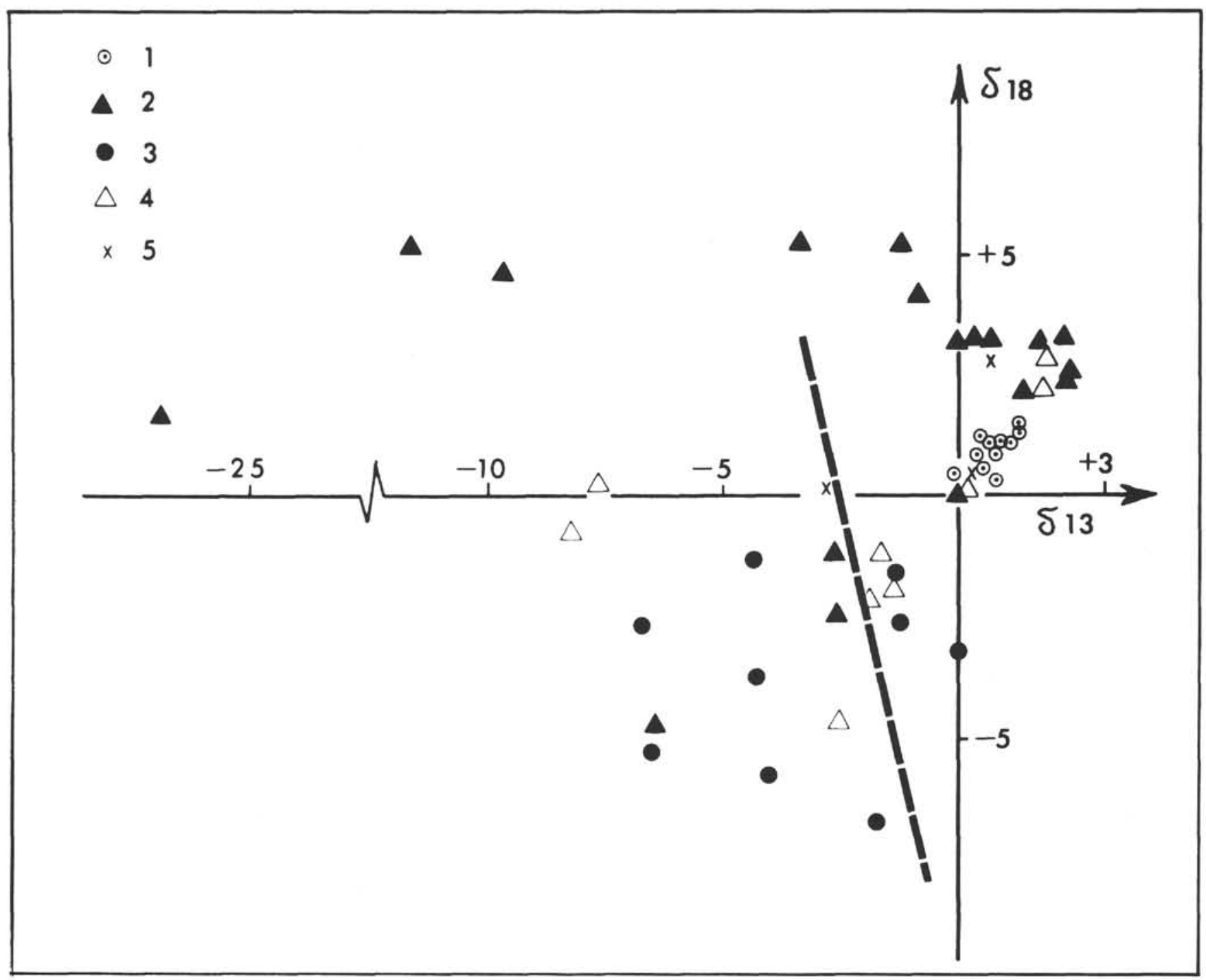

Figure 2. A plot of $\delta O^{18}$ against $\delta C^{13}$ for samples investigated. $1=$ Pliocene and Quaternary pelagic oozes, $2=$ Upper Miocene (Messinian) dolomites, $3=$ Upper Miocene (Messinian) calcites, $4=A$ mixture of the calcites and dolomites, and 5 $=$ Calcites of Middle Miocene (Serravallian) age. The dashed line represents the function $2\left(\delta C^{13}+50\right)=0.5\left(\delta O_{1} 8+50\right)$ given by Keith and Weber (1964) to separate carbonates of marine origin (right of the line) from carbonates of fresh-water origin (left).

apparently crystallized from concentrated water with a modified ionic content.

\section{Oxygen, Sulfur, and Hydrogen Isotopes in the Sulfates}

For natural samples, the effects of isotopic fractionation between the sulfate ion $\left(\mathrm{SO}_{4}{ }^{-}\right)$and the water of crystallization are difficult to relate to experimental data (Longinelli and Craig, 1967; Lloyd, 1967; and 1969; and Misutani and Rafter, 1969).

Oxygen 18 in the Sulfate Ion: Studies of the data $\delta \mathrm{O}^{18}$ values of brines and of gypsum in saline ponds bordering the Mediterranean has shown that the data $\delta \mathrm{O}^{18}$ content of the sulfate ion has been enriched; also precipitated gypsum has an enriched data $\delta \mathrm{O}^{18}$ of +14 to $15 \%$ (Fontes and Schwartz, unpublished data). We have obtained values of 14.3 and $15.1 \%$ in the sulfate of core bit samples of Site 122 and $125 \mathrm{~A}$. We interpret those values as an indication of $\delta 018$ enrichment due in the processes of brine concentration.

It is generally admitted (Longinelli and Craig, 1967) that in the range of biological temperatures and $\mathrm{pH}$, isotopic exchange between the oxygen in sea water and that in the sulfate ion is very slow, with a half reaction time in the range of 100 to 1000 years. It appears that under peculiar conditions of confinement (i.e., inhibited circulation, strong evaporation, high temperatures and high brine concentration) sulfates should more rapidly initiate an isotopic equilibration with the water.

Consequently, and as a present working hypothesis, one can reasonably assume that the measured values of +14.3 and $15.1 \%$ correspond to precipitation of calcium sulfate in situations well isolated from the open sea for which, however, the original supply of sulfate ions was from the open sea. 


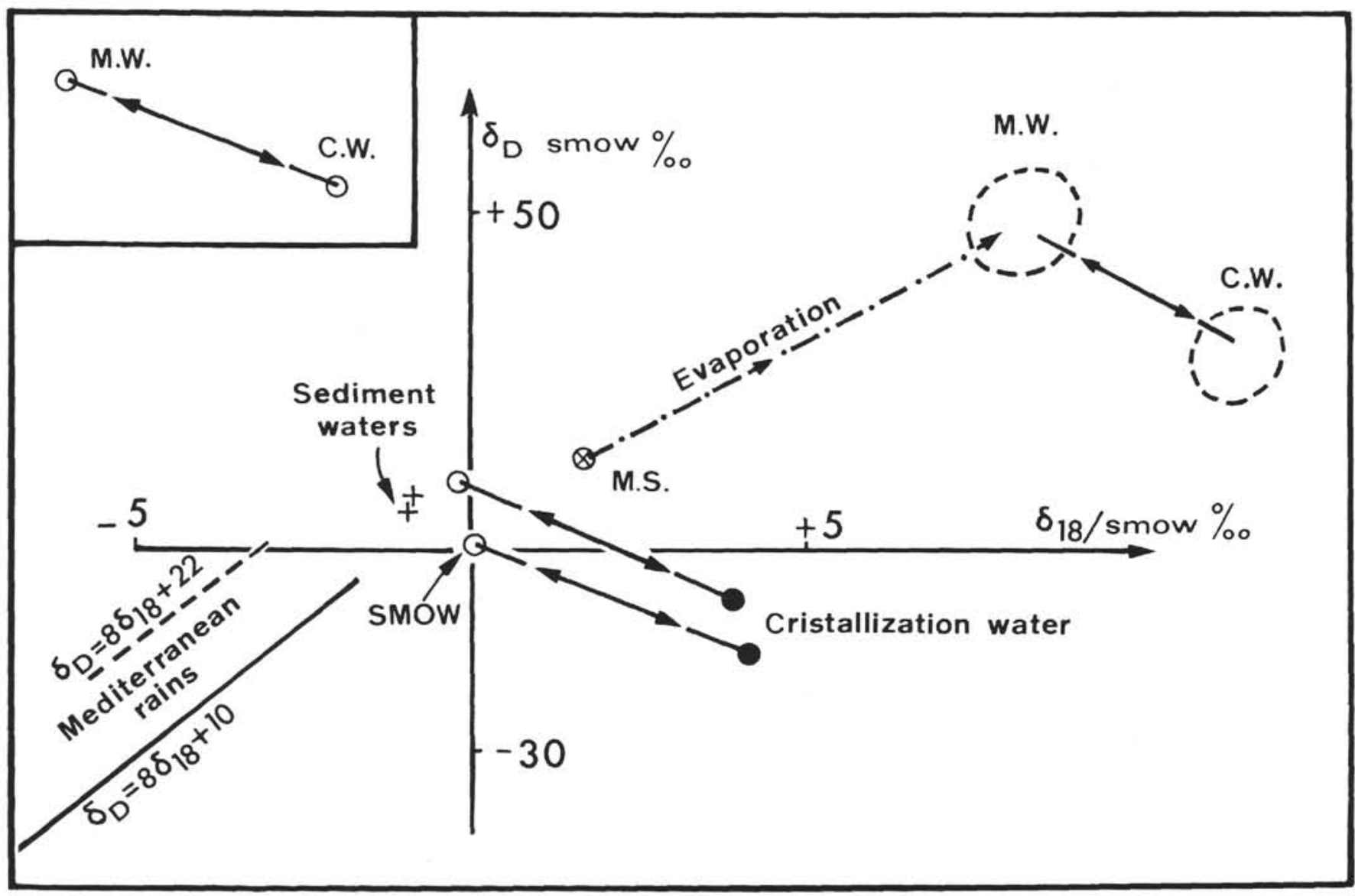

Figure 3. A plot of $\delta D$ against $\delta 018$ for the interstitial waters of Cores $132-25$ and $132-26$ (+ signs) and the crystallization waters of the Core Bit samples from Sites 122 and $125 \mathrm{~A}$ (solid dots). The insert in the upper left hand corner shows the correction (because of fractionation) to be applied to convert the isotopic value of crystallization water (C.W.) to its mother water (M.W.) value. As an example, if present Mediterranean sea water (M.S.) is concentrated by evaporation to precipitate gypsum, the M.W. circle shows the isotopic range of the saturated mother water and the C.W. circle the range of the crystallization water in the newly formed gypsum. At the lower left are the localization lines for worldwide precipitation (solid line) and eastern Mediterranean precipitation (dashed line).

Sulphur 34 in the Sulfate Ion: Two samples of gypsum, one from Site 122 and one from Site 125A, have provided $\delta S 34$ values of +22.0 and $+22.6 \%$ vs. Cañon Diablo; these are similar to measured values from recent marine sulfates. Because $\delta \mathrm{S}^{34}$ values have remained quite constant since the beginning of the Tertiary (Nielson, 1965 and Nielsen and Rambow, 1969), and since the older Mesozoic and Paleozoic salt deposits of Europe and North Africa are characterized by much lower $\delta S^{34}$ values, it is unlikely that erosion of older sedimentary rocks has supplied the sulfate to the Messinian basin. It is more probable, in light of what has already been concluded about the oxygen isotopes, that the sulfate ions were derived directly from the open ocean.

Oxygen 18 and Deuterium in the Water of Crystallization: Isotope fractionation during the hydration of anhydrite to gypsum is known to be an equilibrium or near-equilibrium process (Gonfiantini and Fontes, 1963; Fontes and Gonfiantini, 1967). In the interval of $+15^{\circ} \mathrm{C}$ to $+60^{\circ} \mathrm{C}$, which covers the ordinary range of temperatures for the precipitation of evaporites, the fractionation is also known to be independent of temperature.
The following enrichment factors of the isotopes between the mother water (Vine) and crystallization water can be defined: $\epsilon \mathrm{O}^{18}=+4.0 \%, \epsilon \mathrm{D}=-16 \%$ with $\epsilon \bumpeq \delta$ (mother water) $-\delta$ (crystallization water).

Present-day values close to $+8 \%$ for $\delta \mathrm{O}^{18}$ and $+50^{\circ} \%$ o for $\delta \mathrm{D} v s$. SMOW are obtained for mother water of directly precipitated gypsum from the concentration of Mediterranean sea water, when the original liquid has been concentrated to one-fifth its original volume (Fontes, 1966).

As shown in Table 2, crystallization waters of the selenite (gypsum) crystals from Sites 122 and $125 \mathrm{~A}$, though similar in isotopic composition, cannot correspond to evaporatively concentrated, calcium-sulfate-saturated sea water. These evaporite specimens have quite obviously undergone recrystallization. The macro- and microscopic fabric of the sample from Site 125A (see Figures 14 and 15 of Chapter 7), which indicates complete alabastrization, supports this conclusion.

The question now arises as to the origin of the water leading to the crystallization. If, as shown in Figure 3, we take the isotopic values of the measured crystallization water (solid dots) and correct these data for fractionation 
(open circles) we arrive at a composition for the ancient mother water far different from what would be obtained by taking present day Mediterranean water (circle with a cross) and evaporating it. A clue to the origin of the ancient mother water comes from an examination of interstitial water in the evaporitic marls.

Oxygen 18 and Deuterium in Interstitial Waters: It turns out that the isotopic composition of connate waters of Messinian age, extracted by squeezing sediments from Cores 25 and 26 at Site 132 (see Table 3 and plus sign in Figure 3 ), lies close to the values of the crystallization water corrected for fractionation during the formation of gypsum (open circles of Figure 3). The isotopic composition of the interstitial waters can be attributed to that of seawater without any sign of enrichment by evaporation (Craig and Gordon, 1965). It is believed to antedate the general enrichment of marine water masses in heavy isotopes due to the balancing effect of the glaciations and the relative isolation of the Mediterranean basins. We consider that the mother water, now locked within the sediment both as pore water and crystallization water, is most likely Atlantic Ocean water brought in during brief marine invasions during the Messinian and, in the case of the Site 122 sample at the upper contact of the evaporite layer, by the marine waters of the Pliocene (see Chapter 47). It is unlikely that the ancient mother water was solely meteoric because its corrected values lie well off the trend (dashed line of Figure 3) of rain water from arid or semi-arid areas (Craig, 1961 and IAEA, 1969 and 1970).

If we consider that the mother water was supplied during marine invasions from the Atlantic Ocean, it will be of further interest to compare its inferred isotopic composition (open circles of Figure 3) with that of the Pliocene carbonate sediments deposited at a time when we know there was open communication between the Mediterranean and the Atlantic (Benson, 1971).

\section{ISOTOPIC COMPOSITION OF THE PELAGIC OOZES}

Oxygen and carbon isotope determinations were made on the carbonate fraction of pelagic open-marine sediments of Sites 125A, 126, 129, 132 and 134. The samples from Sites 126 and 129 include sediment of pre-evaporite age (middle Miocene), and the remainder are samples of earliest Pliocene to Quaternary age.

\section{Oxygen and Carbon Isotopes in the Pliocene and Quaternary Sediments}

The Pliocene-Quaternary pelagic oozes are generally rich in calcium carbonate $\left(30 \%<\mathrm{CaCO}_{3}<70 \%\right)$, as shown in Figure 1 of Chapter 30.3 .

The clustering of the isotopic compositions $(+0.24 \leqslant$ $\delta 0^{18} \leqslant+1.35$ and $\left.-0.04 \leqslant \delta \mathrm{C}^{13} \leqslant+1.25\right)$, which appears as the group of open circles with dots in Figure 2, is related to the crystallization of carbonate skeletal material in a large mass of water, which acts as an isotopic buffer. Sample 126-1-4-90, assigned to the "pre-glacial" Pleistocene, is slightly heavier than the Pliocene carbonates and does not show the important variation correlated with the "temperature and/or water-isotopic-composition effect" known for the cold climate epochs of later glacial times. A similar observation has been made by Emiliani et al. (1961) on pericontinental Pliocene/Calabrian deposits.

The most positive values of $\delta \mathrm{O}^{18}$ in the pelagic oozes occurs in Sample 125 A-6-1-25 cm, just above the Miocene/Pliocene contact where a significant amount of the carbonate $(1 / 6$ th) is in the form of detrital dolomite reworked from the subjacent evaporitic marls with a $\delta 018$ of $+5.20 \%$. Detrital dolomite has been observed to have a similar effect on the bulk isotopic composition of carbonate sediment from the Persian Gulf (Sugden, 1963).

The values of -0.78 and $-0.88 \%$ vs. SMOW for the oxygen isotopic composition of the interstitial waters of late Miocene age suggest that the ancient sea water was perhaps 1.5 to $2.3 \%$ lighter in 018 than today. This assumed value of $-0.8 \%$ for Mediterranean Sea water implies that the budget of the Mediterranean Sea was quite different from that of the present. Therefore the values of $+0.24 \leqslant \delta 018 \leqslant+1.33 \%$ U.S.P.D.B. for the earliest Pliocene oozes of Cores 19 to 21 of Site 132 suggest that the temperature was near $8^{\circ} \mathrm{C}$ to $13^{\circ} \mathrm{C}$ at maximum rather close to that of the recent Mediterranean bottom water, and perhaps lower. This problem will be discussed in greater detail in Part V of Chapter 47. However, we can state that the situation revealed in the present study is quite distinct from the compositional balance of the oceanic masses as discussed by earlier authors (i.e. Emiliani, 1966; Shackleton, 1967; Dansgaard and Tauber, 1969; L'etolle et al., 1971).

\section{Oxygen and Carbon Isotopes in the Middle Miocene Sediments}

The carbonate content of the middle Miocene (Serravallian) sediments of Site 126 is only 3 to 12 per cent by weight but it is entirely calcitic-mostly nannofossils. The isotopic data show a much broader scatter (+ signs in Figure 2) than for the Pliocene and Quaternary sediments with a $\delta \mathrm{C} 13$ value of $-2.83 \%$ for the core catcher sample of Core 6. Perhaps the light values are related to density stratification during Serravallian time, leading to oxygen depletion in the bottom water mass of the Ionian Basin (no benthic fauna was present). It is also possible that some part of the Serravallian calcite was recrystallized during Messinian immersions.

Similar light values have been recorded in Quaternary sediments from layers of sapropel mud rich in organic matter and influenced by exchanges of water with the Black Sea.

Markedly negative values of the $\delta \mathrm{C} 13$ were observed in the samples from Core 3 of Hole 129. These samples contain the euryhaline ostracod Cyprideis (see Chapter 36.2), which is suggestive of an alkaline lake deposit.

\section{CONCLUSIONS}

The carbonates of the evaporite layer exhibit a large scatter in their $\delta 018$ and $\delta \mathrm{C}^{13}$ values. The calcites are all negative, whereas the dolomites have generally positive $\delta 018$ values with $\delta \mathrm{C} 13$ values that reach $-26.9 \%$ PDB. Some of the fine-grained dolomite is interpreted as a primary precipitate or a very early diagenetic product. As a whole, the $\delta 018$ range for the carbonates is $-6.81 \leqslant \delta 018 \leqslant$ +7.13 . We believe these measurements indicate that at 
times during the Messinian "crisis of salinity" the Mediterranean basins became isolated from the open ocean and were supplied to a great extent by river and rain water.

The markedly negative values of $\delta \mathrm{C}^{13}$ in the dolomites might be related to diagenesis associated with carbon dioxide derived from organic matter depleted in the heavier isotope. The positive values might correlate with the intervention of atmospheric carbon dioxide at a time when the basins were very shallow and abiotic.

The sulfates examined appear to be of marine origin, indicating periodic influxes of appreciable amounts of water from the open ocean. This conclusion is corroborated by the presence of marine fossils (foraminifera and coccoliths) in interbeds within the evaporite sequence.

The hydration of anhydrite to gypsum and the formation of selenite at Sites 122 and $125 \mathrm{~A}$ in both the western and eastern Mediterranean basins was caused by integration of marine sea water in the crystal lattice.

The late Miocene/early Pliocene water was perhaps significantly lighter (perhaps 1.5 to $2.3 \%$ ) in 018 than present day Mediterranean water. The earliest Pliocene surface water at Site 132 in the Tyrrhenian Basin was probably as cold or colder than present day Mediterranean bottom water.

Negative $\delta \mathrm{C}^{13}$ values from the middle Miocene (Serravallian) pre-evaporite calcite sediments are correlated with evidence that the Mediterranean basins were stagnant or nearly stagnant at that time, leading to an enrichment of organic matter in the stratified surface water mass.

\section{ACKNOWLEDGMENTS}

We are greatly indebted to the U.S. National Science Foundation, sponsor of the Deep Sea Drilling Project. The Centre National D'Exploitation des Oceans and the Centre National de la Recherche Scientifique provided the French participants to the shipboard staff of Leg 13.

We are grateful to Mrs. L. Merlivat who analyzed waters for deuterium at the C.E.N. in Saclay (France) and M.F. Melières (Universite de Paris) who carried out a good part of the X-ray diffraction analyses.

We owe thanks for most of the analytical part of this work to Miss A. Filly and Miss M. C. Sichère, Financial support was provided by Laboratoire Associé n ${ }^{\circ} 13 \mathrm{du}$ Centre National de la Recherche Scientifique.

Discussions with K. J. Hsü and J. R. Lawrence have been helpful.

\section{REFERENCES}

Benson, R. H., 1971. Ostracods as indicators of threshold depth in the Mediterranean during the Pliocene. $A b$ stract. 83 Int. Sedim. Congr. Heidelberg.

Cheeney, E. S. and Jensen, M. L., 1965. Stable carbon isotopic of biogenic carbonates. Geochim. Cosmochim. Acta. 291331.

Clayton, R., Jones B. F. and Berner R. A. 1968. Isotope studies of dolomite formation under sedimentary conditions. Geochim. Cosmochim Acta. 32, 415, 432.

Craig, H., 1961. Isotopic variation in meteoric waters, Science. 133, 1702.

$\longrightarrow$ 1965. The measurements of oxygen isotope paleotemperatures. Spoleto 1965, Consiglio Nazionale delle Ricerche. E. Tongiorgi ed., 161-182.

Craig, H. and Gordon L. I., 1965. Deuterium and oxygen 18 variations in the Ocean and the Marine Atmosphere.
In Stable Isotopes in Oceanographic Studies and Paleotemperatures. Spoleto 1965. Consiglio Nazionale delle Ricerche. E. Tongiorgi ed. 9-130.

Dansgaard, W. and Tauber H., 1969. Glaciers Oxygen 18 Content and Pleistocene Ocean Temperatures. Science. $166,499$.

Dessau, G., Gonfiantini R. and Tongiorgi E., 1960. L'origine dei giacimenti solfiferi italiani alla luce delle indagini isotopiche sui carbonati della serie gessososolfifera della Sicilia. Lo Zolfo., 15-16, 9.

Deuser, W. G., 1970. Extreme variations in Quaternary dolomites from the continental shelf. Earth and Planet. Sci. Letters, 8, 118.

Emiliani, C., Mayeda T., and Selli R. 1961. Paleotemperature Analysis of the Plio-Pleistocene Section at the Costella, Calabria, Southern Italy. Bull. Geol. Soc. Am., 72,679 .

Epstein, S., Buchsbaum R., Lowenstam H. A. and Urey H. C., 1953. Revised carbonate waterisotopic temperature scale. Bull. Geol. Soc. Am. 64, 1315.

Fontes, J-Ch., 1966. Intérêt en géologie d'une étude isotopique de l'évaporation. Cas de l'eau de mer. C. $R$. Ac. Sc. 263, 1950.

Fontes, J-Ch., and Gonfiantini R. 1967. Fractionnement isotopique de l'hydrogène dans l'eau de cristallisation du gypse. C.R. Ac. Sci., Paris. 265, 4.

Fritz, P., 1971. Geochemical characteristics of dolomites and the $\mathrm{O}^{18}$ content of middle Devonian oceans. Earth and Planet. Sci. Letters. 11, 277.

Fritz, P., and Smith D. G. W., 1970. The isotopic composition of secondary dolomites. Geochim. Cosmochim. Acta. 34, 1161.

Gonfiantini, R. and Fontes J-Ch., 1963. Oxygen isotopic fractionation in the water of crystallization of gypsum. Nature. 200, n $4907,624$.

Hathaway, J. C. and Degens E. T., 1968. Methone-Derived Marine Carbonates of Pleistocene Age. Science. 165, 690.

I.A.E.A., 1969, 1970. Environmental Isotope Data World Survey of Isotope Concentration in Precipitation $n^{\circ} 1$ 1953-1963; $n^{\circ} 2$ 1964-1965. I.A.E.A., Vienne, technical reports $\mathrm{n}^{\circ} 96$ and 117 .

Keith, M. L. and Weber J. N., 1964. Carbon and oxygen isotopic composition of selected limestones and fossils. Geochim. Cosmochim. Acta, 28, 1787.

Letolle, R., De Lumley H., Pillard F. and VergniaudGrazzini C. 1971. Essai d'échelle paléoclimatique de la Méditerranée occidental basée sur l'analyse isotopique des tests marins fossiles. Abstr. 8e Int. Sedim. Congr., Heidelberg. A paraitre dans Quaternaria.

Lloyd, R. M. 1968. Oxygen isotope behavior in the sulphate water system. J. Geol. Res. 73, 6099.

Longinelli, A. and Craig H., 1967. Oxygen 18 variations in sulfate ions in sea water and saline lakes. Science. 156, $\mathrm{n}^{\circ} 377156$.

Mizutani, Y. and Rafter T. A., 1969. Oxygen isotopic fractionation in the bisulphate ion-water system. N. Z.J. Sci. 12, 1, 54 .

Mook, W. G. 1971. Paleotemperatures and chlorinites from stable carbon and oxygen isotopes in shell carbonate. Paleogeography, Paleoclimatology, Paleoecology. 9, 245.

Nielsen, H. 1965 Schwefelisotopes im marinen Kreislauf und das $\mathrm{S}^{34}$ der früheren Meere. Geol. Rundschau. 55, 160 .

Nielsen, H. and Rambow D. 1969. S. Isotopen unter Suchungen an sulfaten nessischer Mineralwässer. Notizbl. hess L. Amt. Bodenforsch. 97352. 
Shackleton, N., 1967. Oxygen Isotope Analyses and Pleistocene Temperatures reassessed, Nature. 215, 15.

Sugden, W., 1963. Some aspects of sedimentation in the Persian Gulf. Sediment Petrol. 33, 2, 355.

Sharma, T. and Clayton, R. N., 1965. Measurements of $\mathrm{O}^{18} / \mathrm{O}^{16}$ ratios of total oxygen from carbonates. Geochim. Chosmochim. Acta. 29, 1347.
Ruggieri, G. 1967. The Miocene and later evolution of the Mediterranean Sea. Sipt. Assoc. Publ. 1, 283.

Ruggieri, G. and Greco, A., 1965. Studi geologici e paleontologici su capo Milazzo con particulare regardo al Milazziano. Geol. Romona. 1, 41.

Russell, K. L. Deffreyes, K. S., Fowler, G. A. and Lloyd, R. M., 1967. Marine Dolomite of Unusual Isotopic Composition, Science. 155 n $^{\circ} 3759,189$.

\title{
30.3. STABLE OXYGEN AND CARBON ISOTOPE VARIATIONS IN BULK CARBONATES FROM LATE MIOCENE TO PRESENT, IN TYRRHENIAN BASIN - SITE 132
}

\author{
James R. Lawrence, Lamont-Doherty Geological Observatory, Columbia University, Palisades, New York
}

\section{INTRODUCTION}

This investigation was undertaken to determine to what degree the $0^{18} / \mathrm{O}^{16}$ and $\mathrm{C}^{13} / \mathrm{C}^{12}$ ratios of full carbonate sediments represent depositional conditions versus diagenetic conditions. If appreciable diagenesis can be discounted, then the measured isotopic values should reflect the surface water temperature at the time of growth of the carbonate organisms and the $0^{18} / \mathrm{O}^{16}$ and $\mathrm{C}^{13} / \mathrm{C}^{12}$ content of the surface waters. If, on the other hand, significant isotopic exchange has occurred during diagenesis, the isotopic values should yield information about the temperatures and mechanisms of diagenesis.

The sediments from Site 132 consist of evaporites of Miocene age overlain unconformably by a continuous section of pelagic oozes of Pliocene to Recent age (see Chapter 13). The Miocene evaporites consist mostly of gypsum, dolomite, calcite and silicate detritus and contain, in several horizons, brackish water fossils. These sediments have undergone lithification and recrystallization to a moderate degree since deposition. The Plio-Pleistocene oozes consist of coccoliths (70-95\%) and foraminiferal (5-30\%) shells formed in surface and near surface waters, plus a variable amount of silicate detritus (see Figure 1). Very little lithification and recrystallization has taken place in these younger sediments (see Chapter 13).

Bulk samples, representing one centimeter horizons at 19 intervals throughout the entire core, were analyzed for $\mathrm{O}^{18 / \mathrm{O}^{16}}$ and $\mathrm{C}^{13} / \mathrm{C}^{12}$ content of the carbonate fraction by the method described by McCrea (1950). All $\mathrm{C}^{13} / \mathrm{C}^{12}$ and $0^{18 / 016}$ analyses are reported in the $\delta$-notation with $\delta$-values being reported with respect to PDB and SMOW, respectively.

\section{RESULTS AND DISCUSSION}

Variations in the $\mathrm{CaCO}_{3}$ content of sediments from Site 132 are shown in Figure 1. There is an abrupt increase in

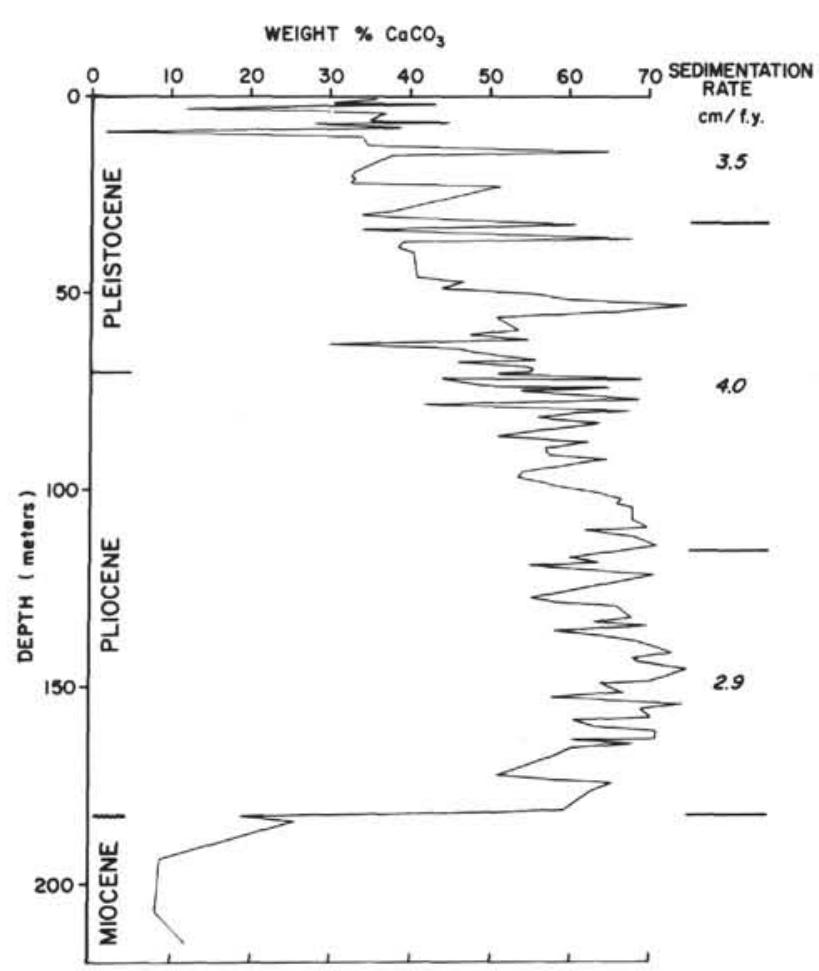

Figure 1. Weight per cent of $\mathrm{CaCO}_{3}$ in the sediments from Site 132, Leg 13 plotted as a function of depth. The average sedimentation rates in centimeters per thousand years are also shown.

$\mathrm{CaCO}_{3}$ content of the sediments across the MiocenePliocene unconformity. This is not unreasonable considering the drastic change from an evaporite sequence to normal marine pelagic oozes.

The $\mathrm{CaCO}_{3}$ content of the Pliocene sediments is relatively uniform, with a decrease in the upper Pliocene which continues into the Pleistocene. Comparison of the changes 